\title{
Diaspora Turizmi: Balkanlara Seyahat Edenler Üzerinde Sosyolojik Bir Araştırma
}

\author{
Diaspora Tourism: A Sociological Investigation of Those Groups Travelling to Balkans
}

\author{
Sonay KAYGALAK' , S. Emre DILEK², Ebru GÜNLÜ³
}

\begin{abstract}
ÖZET
Araştırma, nitel araştırma yöntemleri desenlerinden biri olan olgubilim (fenomenoloji) deseni üzerinde şekillenmektedir. Çalışmanın amacı, Balkan topraklarını ziyaret eden kişilerin ziyaret amaçlarının, güdülerinin neler olduğunu belirleyebilmek ve bir turist olarak ata topraklarını ziyaret etmelerinin ve bu sayede, anılarını yeniden keşfetmelerinin/anlatılanları yerinde görmenin yarattığı duygu ve düşüncelerini sosyolojik boyutta inceleyebilmektir. Bu doğrultuda, Balkan turuna katılan 11 kişi ile yarı yapılandırımış görüşme formu aracılığıyla yüz yüze mülakatlar gerçekleştirilmiştir. Yapılan analizler sonucunda, araştırmaya katılan kişilerin özellikle eski dönemlerde aile büyüklerinden dinledikleri anılar ve hikayeler ile birlikte merak etme duygusu ile güdülendikleri ve bu nedenle Balkan turlarına katıldıkları ortaya çıkmışır.
\end{abstract}

Anahtar kelimeler: Diaspora, anavatan turizmi, Balkanlar

\section{GíRiş}

Pek çok yazar tarafından ifade edilen dünyanın 'küresel bir ev olma hali', bireylerin, kültürel açıdan kapitalizmin herhangi bir yerinde muhalif bir konum tasarlamasına, başka bir deyişle kimliklerini tarihsel süreç içerisinde özgün bir şekilde korumalarına imkan vermemekte ve bu haliyle de kendilerini "ev içinde evsiz" hissetmelerine neden olmaktadır. Nitekim Leontis (1999) bu durumu, kapitalizmin bir fonksiyonu olarak ele almakta ve insanların tam bir ikilem arasına sıkıştığına vurgu yaparak şu şekilde bir yaklaşım geliştirmektedir; " Kapitalizm, uzak ile yakın arasındaki ontolojik sınırları silerek, ev ya da yurt ile yaban, sıla ile gurbet arasındaki sınırları aşındırarak, 'dünyayı global bir ev' e dönüştürdü ve paradoksal bir biçimde her şeyi 'yersiz-yurtsulaştırarak' öncelikle 'ev'i imkansız, ele geçmez bir kategori haline getirdi (Leontis'den aktaran: Argın 2003). Bu noktada, söz konusu yaklaşımdan hareketle belki de asıl olarak varılabilinecek sonuç;'birey, hangi toplumda ve hangi zaman diliminde yaşarsa yaşasın daima turist olarak kalacaktır'.

\begin{abstract}
This research is based on phenomenology ehich is one of the qualitative research techniques. The aim of the study is to find out the travel motives of the individuals visiting Balkans and to analyze in sociological context not only their feelings and views of rediscovering their memories where they were once created but also the feel og being a tourist while visiting their ancestors' land. Therefore, in depth interviews were made with 11 people who participated in a Balkan tour via semistructured form. As a result of the analysis, it is found out that these Balkan-Turks were motivated by the memories, stories they have been told by their elders and the antecedent of participating in that tour was" a sense of wonder".
\end{abstract}

Keywords: Diaspora, homeland tourism, Balkans

Işte kapitalizmin, bireyleri kendi toplumlarına yabancılaştırma ve böylelikle 'turistleştirme' sine ek olarak, tarihsel süreç içerisinde özellikle siyasi gelişmelere paralel olarak ait oldukları veya olmayı arzuladıkları vatanlarından sürgün edilmeleri de, zaten 'yersiz-yurtsuz' olan insanların tamamıyla mahkum edilişlerini hızlandıran diğer bir unsur olmuştur. Bu bağlamda da; 'Herhangi bir ulusun veya inanç mensuplarının ana yurtları dışında azınlık olarak yaşadıkları yer,' 'Herhangi bir ulusun yurdundan ayrılmış kolu, kopuntu' gibi anlamlara gelen 'diaspora' kavramı ortaya çıkmaktadır (www.diaspora. nedir.com). Bu durum beraberinde, kapitalist sistemin yaratmış olduğu çapraz ateşin etkisinde kalan insanların turistleşmesine bağlı olarak, diaspora ve turizmin birbirinden ayrı düşünülemeyecek olgular olmasına neden olmaktadır. Nitekim turizm, kapitalizmin bir metaforu olarak (Urry 2003) ele alınıp etimolojisi incelendiğinde; 'Tour' sözcüğünün Fransızca'da 'yolculuk' anlamına geldiği gibi, 'dönüş' ve daha da ilginci 'hile' anlamlarını taşıdığı ve biraz oyuncul bir şekilde bu üç anlam harmanlandığında turizmin 'bir gidiyormuş gibi yapma' jesti içerdiği yani gidilip gelindiği halde içinde bir'sahtelik' barındırdığına değinilmektedir (Argın 2003).

\footnotetext{
${ }^{1}$ Araştırma Görevlisi, Dokuz Eylül Üniversitesi, İşletme Fakültesi, Tınaztepe Kampüsü,35160, İzmir. sonay.kaygalak@deu.edu.tr

${ }^{2}$ Araştırma Görevlisi, Dokuz Eylül Üniversitesi, İşletme Fakültesi, Tınaztepe Kampüsü,35160, İzmir. s.emre.d@hotmail.com

${ }^{3}$ Doç. Dr. Dokuz Eylül Üniversitesi, İşletme Fakültesi, Tınaztepe Kampüsü,35160, İzmir. ebru.gunlu@deu.edu.tr 
Bu bağlamda, diaspora ve turizm olguları arasında güçlü bir bağ olduğu görülmektedir çünkü, turizm eğer bir 'gidiyormuş gibi yapma' haliyse ve diaspora da yersiz-yurtsuz bir yaşamın kimliğini içerisinde barındırıyorsa bu iki olguyu birbirinden bağımsız ele almak pek de mümkün görünmemektedir.

Sonuç olarak kapitalizmin desteğini de arkasına alarak, diasporayı yaratan faktörün siyasal gelişmelere bağlı ve zorunlu bir sürgünlük durumu olduğu düşünüldüğünde, sürgün hayatına mahkum bırakılan insanların da bir zamanlar ait olduklarını düşündükleri vatanlarına karşı bir özlem duymamaları düşünülememekte ve bu noktada, belki de yapısal olarak kendisini kapitalizmin bir öncüsü olarak konumlandıran ancak aynı zamanda zorunlu olarak da olsa sürgünlüğe karşı da duran turizmin devreye girmesi kaçınılmaz olmaktadır zira Argın'ın da ifadesi ile turizm, 'uzaktaki ev' dir (Argın 2003).

\section{YAZIN}

\section{Diaspora Kavramında Semantik Tartışma: Evrensel Olmama}

Yazında diaspora kavramı üzerine çeşitli araştırmalar yapılmıştır. Diaspora gerek medyada gerek akademik yazında siyasi/ekonomik olarak ele alındığında 'kötü', 'bela', 'muhalif', 'marjinal' grupları betimlemekte iken sosyolojik olarak irdelendiğinde ise 'özlem,' 'ziyaret,' 'aidiyet,',nostalji' gibi kavramları ifade etmektedir. Bu bağlamda tarihte siyasi ikilemlerin ve çatışmaların yaşandığı gruplara ilişkin algıdan farklı olarak bu araştırmada olayın sosyolojik tabanı sorgulanmakta ve 'iyi' algısı üzerine kurgulanmaktadır. Ancak söz konusu ayrımı yapmak diaspora kavramını detaylandırıp, açıklamak ile mümkün olmaktadır. Grekçe diasperien, dia(-in üzerine) ve sperien (ekmek/tohumları saçmak) terimlerinden türeyen diaspora, tarihsel olarak göç veya sürgün hareketleri aracılığıyla anavatanlarından edilen yurtsuz insan topluluklarını ifade etmek için kullanılan bir metafordur. Genel olarak aynı çağrışımları yapmasına rağmen, bu konuda çalışan araştırmacıların çoğu kavramı farklı siyasi, etnik, ulusal durumları tanımlamak için kullanmışlardır. Modern anlamda diaspora kavramı; genellikle büyük çoğunluğu en az birkaç kuşak için, tarihi vatanlarına (yalnızca sembolik veya duygusal olsa bile) bazı bağlarını koruduğu halde, memleketlerinden uzakta yaşayan etnik gruplara atıfta bulunmaktadır (Remenncik 2007).

Her ne kadar yapılan araştırmalarda "diaspora" açıklanmaya çalışılsa da; sorunlu, genelde sadece tek bir deneyime atfedilen - örneğin, Yahudi, ancak yine de pek çok örneğe ve forma uyarlanabilen bir kavram olarak gündeme gelmektedir. Öte yandan zamanla sadece göçmenlerin odak noktasına oturtulduğu ha- reketliliği temsil eden bir 'benzetme' olarak daha da karmaşık bir hal almıştır. Oysa diaspora, göç nedeni ile ortaya çıkan 'etnik azınlık' tan daha çok şey demektir. Diaspora olabilmek için 'ulus ötesi bir varoluş' şarttır. Öte yandan 'zaman' gerekmektedir. Belli bir süre geçmiş olması ve süregelen bir durum olması esastır (Schulz ve Hammer 2003).

Bir grubun diaspora olarak adlandırılmasında en temel kriter; üyelerin anavatanlarına ve dolayısıyla kendi kültürel aidiyetlerine 'bağlılık'larıdır. Bu nedenle aslında her diaspora aynı zamanda 'kültürel' bir diasporadır. Anavatana ve ulusa ait kolektif kimlik bireyleri kendi aidiyetleri doğrultusunda davranmaya yönlendirmektedir (Cohen 1997). Coles ve Timothy (2002)'e göre ana vatan ziyareti ata topraklarına manevi bir bağ hisseden bireylerin oluşturduğu hareketliliktir. Anavatan ile misafir ülke arasında kurulan ilişki ağı her zaman aktif olmasa da bireylerin geri dönüş arzusu anavatan ile ilişkiyi sıklıkla aktif kılmaktadır. Bu durum göç eden ilk kuşağın bu bağı canlı tutma arzusu ile kendi kültürlerini ikinci ve üçüncü kuşağa aktarma çabasını geliştirmektedir. Bu, bireylerin göç hikayesi kadar aynı zamanda bir kültür göçü hikayesinin de başlamasına neden olmaktadır. Bu durum"seyahat eden kültürler" olarak adlandırılmaktadır. Burada kastedilen grubun kendi kültürlerini göç ettikleri yerlere taşımları kadar, göç edilen yerdeki kültürü benimsemeleridir.

Tüm bu kriterlere vurgu yapılmış olmasına rağmen Başer (2013), diasporanın evrensel bir karşılığı olmadığına dikkati çektiği kitabında semantik tartışmaya dikkati çekmektedir. Başer (2013)'in dikkati çektiği araştırmacılar ve diaspora tanımları ile yaklaşımlarının özetlendiği tablo 1 aşağıda yer almaktadır. 
Tablo 1. Diaspora Tanımı, Kriteri ve Eleştirel Yaklaşımlar

\begin{tabular}{|c|c|c|}
\hline Araştırmacı & Tanım / Kriter / & Eleştiri \\
\hline Safran (1991) & $\begin{array}{l}\text { Grup üyelerinin birden fazla ülkeye dağılmış olması, Geç- } \\
\text { mişe ve anavatana dair bellek ve mitler bütünü, İkamet et- } \\
\text { tikleri ülkeye uyum sağlayamama, Anavatan dönüş hayali, } \\
\text { Anavatan için çaba sarf etme ve çıkarlarını gözetme, } \\
\text { Grup bilinci ve dayanışma. }\end{array}$ & \multirow{2}{*}{$\begin{array}{l}\text { Ortaya çıkış noktası Yahudi ve Ermeni vakalarıdır. } \\
\text { Diğer bir deyişle, ilhamını Yahudi ve/veya Ermeni } \\
\text { diasporasından almakta, mevcut durumu yansıtma- } \\
\text { maktadır, çünkü 'zaman' grup amaç ve eylem ruhunu } \\
\text { değiştirmektedir. } \\
\text { Cohen (2008), Safran'ı eleştirerek sadece Yahudi di- } \\
\text { asporası için geçerli olduğunu, tanımlarında yer alan } \\
\text { 'travmatik bir tecrübe' tanısının geçerliliğini kaybetti- } \\
\text { ğini ifade etmektedir. Shuval (2007)'e göre sarsıcı bir } \\
\text { olay sonucu göç etmiş olmak ana kriter değildir. Ba- } \\
\text { uböck (2010)'e göre sarsıcı tecrübesi olmayan gruplar } \\
\text { da göç tecrübesi gerçekleştikten çok sonra ulusötesi } \\
\text { faaliyetlere katılabilirler. }\end{array}$} \\
\hline Safran (2007) & $\begin{array}{l}\text { Ortak bir anavatan ve ortak bir tarihi mirasa sahip olma, } \\
\text { Anavatandan gelen kültürel ve/veya dini değerlere sahip } \\
\text { çıkma ve yaşadıkları ülkelerde azınlık olarak bu değerleri } \\
\text { yaşatma, Anavatana aidiyet, Aidiyetin örgütsel mekaniz- } \\
\text { malara yansıması. }\end{array}$ & \\
\hline $\begin{array}{l}\text { Anderson } \\
(1992,1998)\end{array}$ & Uzaktan milliyetçiliktir. & $\begin{array}{l}\text { Olumsuz bir anlam içerir. Diasporadakiler, uzaktan } \\
\text { milliyetçilik yapan, anavatanda siyasi, ekonomik, sos- } \\
\text { yal olaylar ile bağlantılı olan ancak sonuçlara katlan- } \\
\text { masına gerek olmayan, sorumsuzlukla hareket eden } \\
\text { gruplar olarak tasvir edilmektedir. }\end{array}$ \\
\hline Skrbis (2001) & $\begin{array}{l}\text { Uzaktan milliyetçilik olgusunda; } \\
\text { Siyasi aktörlerin varlığı, Ulusötesi grubun entegrasyon so- } \\
\text { runları, Ayrımcılık, Yabancı düşmanlığı, politik imkanların } \\
\text { azlığı süreci hızlandırır. }\end{array}$ & $\begin{array}{l}\text { Bazı gruplar için geçerli olabilir- Ermeni ve/veya Ya- } \\
\text { hudi diasporası, herkesi kapsayamaz. Siyasi liderleri } \\
\text { sürgün edilmemiş gruplar da diaspora oluşturabilir- } \\
\text { Meksika, Türk (ekonomik nedenler) }\end{array}$ \\
\hline $\begin{array}{l}\text { Glick-Schiller } \\
(2004)\end{array}$ & $\begin{array}{l}\text { Çok yönlü projeleri olan uzaktan milliyetçilerdir. } \\
\text { Anti-kolonyal hareketler, ayrılıkçı hareketler, anavatandaki } \\
\text { rejimi değiştirmeye yönelik hareketler, siyasi katılım gibi } \\
\text { birbiri ile örtüşebilecek amaçlardır. } \\
\text { Sadece sorumsuzca ve anavatan nostaljisi ile anlamsız } \\
\text { hareket eden gruplardan daha çok anavatana bağlı olan, } \\
\text { anavatandaki siyasi, ekonomik ve sosyal olaylar için za- } \\
\text { man ve çaba harcayan ulusötesi topluluktur. }\end{array}$ & $\begin{array}{l}\text { Tüm ulusötesi eylemleri kapsar, diasporanın rolü üze- } \\
\text { rine bilgi verir ancak uzaktan milliyetçiliğin oluşumu } \\
\text { konusunda bilgi vermez. }\end{array}$ \\
\hline $\begin{array}{l}\text { Braubaker } \\
\text { (2005) }\end{array}$ & $\begin{array}{l}\text { Anavatandan başka alanlara dağılmış olmak, Anavatan } \\
\text { için bir yönelimi olmak, İkamet edilen ülkedeki topluma } \\
\text { karşı sınır belirlemiş olmak, Anavatan olgusu, sınırları res- } \\
\text { men tanınmış bir ülke olabileceği gibi resmi statüsü olma- } \\
\text { yan ve ileride kurulması hedeflenen bir ülke de olabilir, } \\
\text { vatana özlem vardır, Yaşanılan ülkedeki toplum ile sınırın } \\
\text { olması,diğer bir deyişle, yaşadıkları toplumdan tam olarak } \\
\text { soyutlanmadan kendileri için sınır oluşturarak grup daya- } \\
\text { nışması gösterirler, Zaman kavramı önemlidir, sınırlarının } \\
\text { bir nesilden diğerine aktarılması sözkonusudur. Kapalı bir } \\
\text { etnik gruptan ziyade bir duruş, bir talepler bütünüdür. }\end{array}$ & \\
\hline Cohen (2008) & $\begin{array}{l}\text { Gönüllü ayrılan gruplar da diaspora sayılabilir, Diaspora } \\
\text { kimliliğinin pozitif olguları üzerinde de durulmalıdır, Ko- } \\
\text { lektif bir kimliği harekete geçirir, Anavatana ilişkin ciddi } \\
\text { iddiaları olmasa bile asıl ulus ötesi bağlarını korurlar. }\end{array}$ & $\begin{array}{l}\text { Faist (2010)'e göre bu yaklaşımda tüm göçmenlerin di- } \\
\text { aspora olup olmadığı ve ulusötesi gruplarla diaspora } \\
\text { kimliğinin ayrılma noktası belli değildir }\end{array}$ \\
\hline $\begin{array}{l}\text { Adamson } \\
(2008)\end{array}$ & $\begin{array}{l}\text { Toplumsal hareketler gibi devingendir. } \\
\text { Siyasi bağlantı olmazsa olmazdır. }\end{array}$ & \\
\hline Bauböck (2010) & $\begin{array}{l}\text { Diasporanın nesilden nesile akması göçmen gruplardan } \\
\text { farkıdır, Göçmen gruplar yeni göç dalgaları ile beslenir- } \\
\text { ken; diasporalar, yeni göç almadığı halde grup bilincini } \\
\text { nesilden nesile devam ettirerek ulusötesi herhangi bir } \\
\text { gruptan ayrılmaktadır. Özcü yaklaşımı reddeder, Birçok } \\
\text { nesili barındıran bir topluluk, bazı elitlerin çıkarları ve siya- } \\
\text { si projeleri doğrultusunda ulusötesi bir kimlik v bellek ya- } \\
\text { ratılarak oluşur ve hem anavatan hem yaşadıkları ülkelerin } \\
\text { politikimkanları da diaspora ile birlikte incelenmelidir. }\end{array}$ & $\begin{array}{l}\text { Yeni nesillere aktarıldığında onların yaşadıkları top- } \\
\text { lumdan ayrı bir kimlik kurulduğu anlamına gelmeme- } \\
\text { lidir. }\end{array}$ \\
\hline $\begin{array}{l}\text { Lyons ve } \\
\text { Mandaville } \\
(2010)\end{array}$ & $\begin{array}{l}\text { Kendiliğinde oluşmaz, siyasi olguların sonucudur, Anava- } \\
\text { tanı ile kültürel bağları olan herkes diaspora üyesi olamaz, } \\
\text { siyasi süreçler ile ilișkilidir. }\end{array}$ & \\
\hline
\end{tabular}

Kaynak: Başer (2013)'den uyarlanmıştır. 
Öte yandan yine Başer (2013)'in diaspora için dikkat çektiği diğer bir konu ilgili yaklaşımlardır. Araştırmacıya göre, diaspora olgusu çerçevesinde ortaya çı- kan yaklaşımlar ve özellikleri aşağıda genel hatları ile tablo 2'de yer almaktadır;

Tablo 2. Diaspora Yaklaşımları ve Özellikleri

\begin{tabular}{|l|l|}
\hline Yaklaşımın Temeli & Özellikleri \\
\hline Antropoloji & $\begin{array}{l}\text { Kavrama özcü yaklaşmakta ve anavatan dışındaki her birey diasporanın parçasıdır. } \\
\text { Basitleştirilmiş bir yaklaşımdır. } \\
\text { Diasporada göçmen, mülteci, ulusötesi topluluk ve sürgün arasında fark bırakmamaktadır. } \\
\text { Türkiye sınııı dı̧ındaki her Türk diasporanın parçasıdır }\end{array}$ \\
\hline Uluslararası Illişkiler & $\begin{array}{l}\text { Elitler ve onların siyasi amaçları çerçevesinde ele alır. } \\
\text { Odakta sadece lobi ve siyasi faaliyetleri olan bu yaklaşımda post-bellek tartışılmamaktadır. }\end{array}$ \\
\hline Sosyoloji & $\begin{array}{l}\text { Yapısalcı yaklaşımdır.'Seferberlik' üzerinden tanımlamaktadır. } \\
\text { Kimlik, belli sayıda birey tarafından politik ve kolektif olarak sahiplenildiğinde oluşmaktadır. }\end{array}$ \\
\hline
\end{tabular}

Kaynak: Başer (2013)'den uyarlanmıştır.

\section{Diaspora Olgusunun Turizme Yansımaları: Siyasetin Ötesinde Duygusal Aidiyet ve Nostalji}

İngilizce kavramlar olan 'köken turizmi' ve 'diaspora turizmi' Almanca kelimeler olan 'Heimattourismus' (Anavatan turizmi) ve Heimwehtourismus' (Eve Özlem Turizmi)'nde olduğu gibi eşanlamlı olarak kullanılmaktadır. Bu da kök ve turizm boyutlarının altını çizmektedir. Bireylerin genellikle köklerinin olduğu ve ailelerinin anavatanını ziyaret etme eğiliminde olduğu ise bir gerçektir. Akademik perspektiften bakıldığında diaspora ve kökler üzerine yapılan araştırmalar yeni sayılmaktadır. Önceki araştırmalar ise bireylerin anavatanlarına olan turistik hareketlerinin ekonomik etkilerini saptamaya dönük ampirik araştırmalar olarak dikkati çekmektedir. Bu bağlamda, Coles ve Timothy (2004'den aktaran lorio ve Corsale 2013), diaspora ve turizmin pek çok noktada örtüştüğünü öne sürmektedir; a) anavatana seyahat, b) soy ağacını araştırma, c) anavatan vatandaşlarının diaspora topluluklarını ziyareti. Bir başka ülkeye yerleşmeyi etkilediği, uzaktaki akrabalar ile bağları koruduğu, geçmişe yönelik nostaljiyi beslediği, ulusötesi kimlikleri koruduğu hatta tekrar anavatana yerleşmeyi mümkün kıldığı gibi nedenler ile göç sürecinin bir parçası olarak anavatana ziyaret turistik faaliyetin kendisidir.

Argın (2003)'ın ifadesi ile turizmin 'uzaktaki ev' olması diaspora ile turizm olayının 'hareketlilik'ten doğan bağını daha da güçlendirmektedir. Nitekim grupların sosyal bir anlam yüklenen yörelere olan seyahatleri bir noktada diasporanın anavatana olan aidiyet ve hasretini gözler önüne seren bir faaliyettir. 'Uzaktaki eve dönüş ziyareti' bir noktada 'ev' ile 'diaspora'arasındaki sosyal diyalektiğin bir parçası haline gelmektedir (Duval 2010). Bu araştırmada da anavatana dönüş ziyaretleri ile ulusötesi ve diaspora gruplarının arasındaki güçlü ilişki ele alınmakta, diasporanın tanım ve özelliklerinde yoğun olarak işlenen "siyasetin sonucu olma", "anavatandaki ve mevcut yaşanan ülkedeki siyasi hareketleri etkileyebilme, amaçlara yönlendirme" gibi olgudan daha ziyade 'ai- diyet', 'hasret' gibi güdüler irdelenmektedir. Nitekim, ulusötesi ya da uzaktan milliyetçilik olgusu her ne kadar siyasi, ekonomik ve sosyal yapılara bürünse de ulusötesi deneyimde ziyaret sadece 'sosyal bağlar' ile de ilgili olabilmektedir. Bu nedenle söz konusu ziyaret bazen belli bir yer olmamakla beraber, anavatandaki herhangi bir yere dönük gerçekleşebilmektedir. Bu da elbette aileleri ya da arkadaşları ziyaret etmek gibi zaten var olan sosyal ve kültürel ilişkileri güçlendirmek ya da somutlaştırmak gibi bir amaca da hizmet edebilmektedir. Şekil 1, söz konusu ulusötesi hareketliliği bu anlamda özetlemektedir.

Şekil 1. Dönüş Ziyaretinin Kavramsal Yapısı

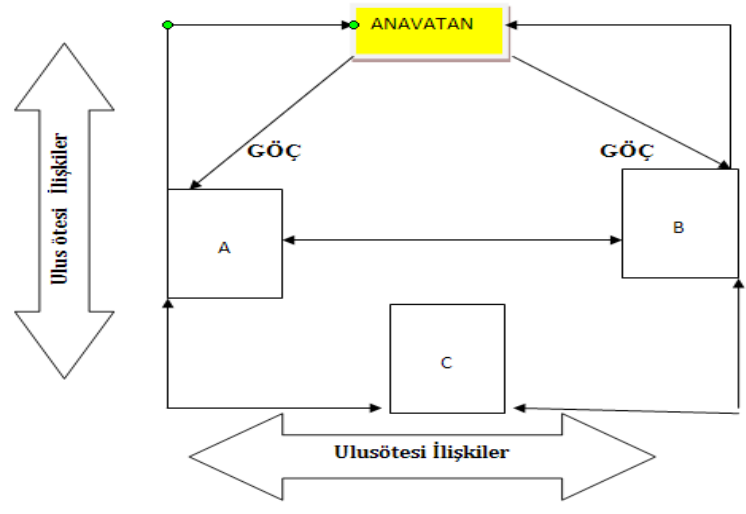

Kaynak: Williams ve Hall (2002)'dan aktaran Duval (2010)

Yukarıda da ifade edildiği gibi, farklı bir ülkede yaşamak ve uyum sağlamanın olumlu yanına rağmen anavatana, kişilere ve yerlere olan nostalji, hasret, ya da kültürel ve sosyal kimlikleri aramak ya da güçlen- 
dirmek gibi birçok güdü anavatana ziyareti gündeme getirmektedir. Yıllar önce gönüllü veya gönülsüz olarak çeşitli nedenler ile göç edilerek ayrıldıkları topraklara seyahatleri 'bireysel miras turizmi', 'etnik turizm', 'arkadaş ve akrabaları ziyaret turizmi', 'köken turizmi', 'diaspora turizmi' gibi farklı şekillerde araştırmalara konu olmuştur. Ne şekilde anılırsa anılsın, yazında tüm olumsuz çağrışımlarına, araştırmalardaki evrenselliği yakalamasına bir türlü fırsat vermeyen farklı yaklaşımlara maruz kalarak olumsuz anlamlar yüklenen 'diaspora'dan hareketle bu araştırmada 'diaspora turizmi' esas alınmış ve siyasi, ekonomik, sosyo-kültürel öncüllerini irdelemenin aksine söz konusu turistik faaliyete katılan bireylerin ne tür duygular, ne tür güdüler ile 'diaspora turizmi'nin bir parçası haline geldikleri sorgulanmaktadır. Öyle ki pek çok birinci kuşak üyesi için anavatana dönüş ve ziyaret daha çok nostaljik bir eğilim ile ortaya çıkmaktadır (lorio ve Corsale 2013).

Bu araştırmanın sorunsalı, diaspora turizmine katılan bireylerin algıları, güdüleri ve deneyimleridir. Buradan hareketle çalışmada ana soru ve bu sorunun amacına uygun olarak alt sorular oluşturulmuştur. Öyle ki, Yin (1994) özellikle nitel araştırmalarda ana soru ve ana sorunun amacına bağlı alt soruların oluşturulmasının önemine değinmektedir. Bu doğrultuda, çalışmanın ana sorusu aşağıdaki şekilde belirlenmiştir;

Diaspora turizmine katılan kişilerin seyahat güdüleri ile yaşadıkları deneyim nasıl ilişkilendirilebilir?

Çalışmanın ana sorusu esas olarak çalışmanın amacına uygun şekilde, bir olgunun derinlemesine anlaşılabilmesi adına, başka bir deyişle diaspora turizmine katılanların sosyolojik analizine yönelik bir bakış açısıyla oluşturulmuştur. Ana soruyu destekler nitelikte ve daha geniş bir bakış açısı ile ortaya konulmaya çalışılan alt sorular aracılığıyla da söz konusu durum detaylandırılmaya çalışılmıştır.

\section{YÖNTEM}

Araştırma, olgubilim (fenomenoloji) deseni üzerinde şekillenmektedir. Olgubilim deseni, farkında olduğumuz ancak derinlemesine ve ayrıntılı bir anlayışa/ kavrayışa sahip olunmayan olaylar, deneyimler, algılar, yönelimler, kavramlar gibi çeşitli biçimlerde karşılaşılan olgulara odaklanmaktadır (Yıldıım ve Şimşek 2011). Bu araştırmada da, "diaspora turizmi" bu türden bir olguya işaret etmektedir.

Araştırmada, nitel araştırma geleneği içerisinde ortaya çıkan amaçlı örnekleme yöntemlerinden biri olan kartopu/zincir örnekleme kullanılmıştır. Söz konusu örnekleme yöntemi, araştırmacının problemine ilişkin olarak zengin bilgi kaynağı olabilecek birey veya durumların saptanmasında özellikle tercih edilmektedir (Patton 1987; Yıldırım ve Şimşek 2011). Bu doğrultuda, 2013 yılı Mayıs ve Haziran ayları içerisinde Balkan turuna yeni katılıp dönmüş olan toplam 11 kişi ile yarı yapılandırılmış görüşme formu aracılığıyla yüz yüze görüşmeler yapılmıştır. Söz konusu bu tur 12 günlük bir süreyi kapsamış ve seyahatler otobüs aracılığı ile gerçekleştirilmiştir. Bu detaylar, orada oluşabilecek duygu, düşünce ve algılar yönünden önem teşkil etmektedir.

Araştırmanın amacı, Balkan topraklarını ziyaret eden kişilerin ziyaret amaçlarının, güdülerinin neler olduğunu belirleyebilmek ve bir 'turist' olarak ata topraklarını ziyaret etmelerinin ve bu sayede, anılarını yeniden keşfetmelerinin/anlatılanları yerinde görmenin yarattığı duygu ve düşüncelerini sosyolojik boyutta inceleyebilmektir.

\section{ARAŞTIRMANIN BULGULARI}

Betimleme, analiz ve yorumlama aşamaları sonucunda 5 farklı başlık altında diaspora turizminin kişiler üzerinde yaratmış olduğu etki tartışılmıştır. Bu bağlamda, demografik bilgiler verildikten sonra, görüşmeler ve kodlamalar neticesinde ortaya çıkan beş farklı boyut detaylı olarak verilmektedir.

Araştırmaya katılanların demografik özellikleri tablo 3'de verilmektedir. Katılımcılar, 40 ile 60 yaş arasındadır. Balkan topraklarında bir süre yaşayan ve Türkiye'ye göç eden katılımcılar olmakla birlikte, Ataları Balkan topraklarında yaşamış ve Türkiye'ye göç etmiş olan katılımcılarda söz konusudur. Daha önce de belirtildiği gibi çalışmada 11 kişi ile görüşmeler gerçekleştirildiyse de, dört kişi çeşitli nedenlerden dolayı demografik bilgilerini paylaşmak istememiştir. Dolayısıyla, söz konusu tabloda yedi kişinin demografik bilgileri bulunmaktadır.

Tablo 3: Katılımcılara Ait Demografik Bilgiler

\begin{tabular}{|c|c|c|c|}
\hline Doğum Yeri & Yaş & $\begin{array}{c}\text { Türkiyede } \\
\text { Yaşadığı Yıl }\end{array}$ & $\begin{array}{c}\text { Göç Etme } \\
\text { Yılı }\end{array}$ \\
\hline Üsküp & 57 & 48 & 1965 \\
\hline Vranya & 56 & 55 & 1960 \\
\hline Bursa & 41 & 41 & 1959 \\
\hline Vranya & 64 & 54 & 1960 \\
\hline Vranya & 58 & 54 & 1959 \\
\hline Akhisar & 54 & 54 & 1954 \\
\hline Alaçatı & 58 & 58 & 1913 \\
\hline
\end{tabular}




\section{- Tarihsel Süreç (Göç, Nedenleri, Balkanlar ile Bağları Akrabalık vb.)}

Katılımcılar ile yapılan görüşmelerdeki temel konulardan birtanesi Türkiye'ye göçlerinin nedenlerini bulmaktır. Söz konusu nedenlerin irdelenmesi, katılımcıların güdülerinin ne şekilde ortaya çıkabileceğine işaret etmektedir. Nitekim, Cohen (2008), diasporayı nitel olarak sınıflandırma amacı ile beş 'kavram' - mağdur, imparatorluk, işgücü, ticari, yurtsuz- kullanmayı tercih etmekte, bu tür bir sınıflandırma yapmanın da grupların önem arz eden özelliklerinin altını çizmek için gerekli olduğunu ifade etmektedir.

Katılımcılara göç nedenleri sorulduğunda alınan yanıtlara göre; siyasi, dini, sosyo-kültürel ve ekonomik baskılar, kendini ifade edememe, mal varlığına el konulması, temsil hakkının elden alınması temel göç nedenleri olarak ortaya çıkmaktadır. Bu kapsamda örnek bir ifadeye aşağıda yer verilmektedir;

"Atalarımızın Türkiye'ye göç etme nedenlerini siyasi, dini, sosyo-ekonomik baskılar ve kendini ifade edememe olarak açıklayabilirim. Ailemden aldığım bilgiler de bu yöndedir. Nitekim, onlarda dini özgürlüklerin olmaması, kendini ve kimliğini yeterince ifade edememe, sosyo-ekonomik haklardan mahrum kalma gibi nedenlerden bahsetmişlerdi. Zaten hala Balkanlar'da yaşayan akrabalarımız var. Amcam, amcamın çocukları ve halamlar orada yaşıyorlar".

\section{Katılımcı 1}

\section{- Sosyo-Kültürel Durum}

Araştırmada üzerinde durulan konulardan bir tanesi katılımcıların ata toprakları ile olan yakınlıkları; Balkan dillerini bilip bilmedikleri, Balkan topraklarına ait kültürel etkinlikleri yerine getirip getirmedikleridir. Verilen yanıtlar ele alındığında çoğu katılımcı mensubu oldukları etnik kökene ait bir takım sosyal ve kültürel etkinlikleri devam ettirdiklerine değinmişlerdir. Nitekim diaspora olabilmek anavatana yani kendi kültürel aidiyetlerine sahip olmayı gerektirir (Cohen 1997) olabilmek Ancak ata topraklarına olan ilgi ve bağlılıkta nesiller arası farklılar söz konusudur.

"Ailemin tüm fertleri Arnavutça biliyor ve kullanıyor. Ben de konuşabiliyorum. Evde Türk yemekleri dışında Arnavut yemekleri de yapılıyor. Bunun yanı sıra, kültür dayanışma derneği aracılığıyla halk oyunları faaliyetleri de yapılmakta. Tüm bunlar kendimi hem Türk hem de Arnavut olarak tanımlamama neden olmaktadır. Kısacası, kendimi her iki etnik kökene de ait hissediyorum."

\section{Katılımci 3}

\section{- Motivasyon}

Katılımcılar ile yapılan görüşmelerde elde edilmek istenen konulardan biri ata topraklarını ziyaret etme nedenleri, hangi motivasyonla kaçıncı kez ziyaret ettikleri ve ziyaretleri süresince kendilerini nasıl hissettikleridir. Alınan görüşler katılımcıların çoğunlukla akrabalarını, anne ve babanın yaşadığı yeri, doğdukları toprakları ziyaret etme, kendilerine anlatılardan dolayı oluşan merak gibi nedenlerle katıldıklarını göstermektedir. Nitekim katılım nedenlerinin merak, kimlik arayışı ve/ veya kimliğini onaylatma (Hughes ve Allen 2010; lorio ve Corsale 2013) faktörlerine dayandığı söylenebilir.

"Çoğu arkadaşıma ata topraklarına ziyaret etmeyi öneren benim. Çeşitli araştırmalar sonucunda 3. Nesil olarak bizlerin bir kimlik sorgulamasına girdiğini gördüm. Yine böyle bir arayıştayken internet ortamında Lozan mübadilleri vakfının kurulduğu yıllarda, ilginç bir sayfaya rastladım. Yunanistan da bulunan 795 tane köyün hem Türkçe hem de yunanca isimleri vardı. Osmanlı devlet arşivlerinden mübadele ile gelenlerin Türk heyetine verdiği mal beyanları var, onları alıp Türkçe tercüme ettirdim. Bunların hepsi bir manevi tatmindi benim için. Bunları arkadaşlarımla paylaştım ve köylerinin isimlerini söyledim. Insanlardaki merak duygusu ile ilgi çekti ve gezilerimizi yaptık. Insanlar geçmişi yâd etti. Babalarımızın dedelerimizin yaşadığı köyleri yerleri ziyaret ettik."

\section{Katılımal 9}

\section{- Yabancılaşma ve Güvenlik}

Yabancılaşma ve güvenlik boyutu, asıl olarak katıIımcıların ata topraklarına yapmış oldukları seyahatte kendilerini birer yabancı olarak hissedip hissetmedikleri ve bu bağlamda, bir güvenlik endişesi taşıyıp taşımadıklarını ortaya koymaya yöneliktir. Nitekim yabancılaşma, "bireyin toplumsal, kültürel ve doğal çevresine uyumunun azalması, çevresi üzerinde denetimini kaybetmesi ve giderek çaresiz kalarak yalnızlaşması" şeklinde veya "kişinin kendini bir topluma veya bir gruba ait hissedememesi" olarak tanımlanmaktadır (Ofluoğlu ve Büyükyılmaz 2008). Araştırmanın bu kısmında da, Marx'ın (2004) dört boyutta ele almış olduğu yabancılaşma kavramı (emeğe, iş sürecine, doğaya ve kendine yabancılaşma) toplumsal ve kültürel açıdan ele alınmaktadır. Yabancılaşmaya bağlı olarak diğer bir konu ise güvenliktir. Öyle ki, insanların toplumsal ve kültürel yabancılaşmaya bağlı olarak güvenlik konusunda da endişe duymaları doğru orantılı bir ilişki olarak ifade edilebilir. Başka bir deyişle, topluma ve kültüre yabancılaşan bireyin güvenlik endişesi de artacaktır. Ancak, araştırmada bu türden bir sonuca rastlanmamıştır.

"Oradaki akrabalarımız çok sıcak ve içtenler ve daha düşkünler akrabalarına. Illk gittiğimizde de hiç tanımıyorduk, ama hiç de endişe duymadan gittik. Önemli 
olan kan bağıydı. Her akşam bir yere götürdüler, ya da birileri bizi ziyarete geldi. Babamı görmüş gibi oldum gidince, insan çok duygulanıyor."

\section{Katılımcı 10}

\section{- Sosyal (Toplumsal) Kimlik}

Toplumsal aidiyet, katılımcıların kendilerini hangi etnik kökene ve kimliğe ait hissettiklerini belirlemeye yönelik olarak sorulan sorular neticesinde ortaya çıkmıştır. Nitekim, Aydın (1999) kişinin kendisini hangi sosyal (toplumsal) kimliğe ait hissettiğinin; kişinin kendisini, kimliği oluşturan topluluğa ait hissedip hissetmemesiyle doğru orantılı olduğunun altını çizmektedir. Dolayısıyla, kimliği oluşturan iki bileşenin ise tanınma ve tanımla ile aidiyet olduğu söylenmektedir. Öyle ki, Kağıtçıbaşı da (2010) benzer bir ifade ile sosyal (toplumsal) kimliğin gruba ya da topluma olan aidiyetlik hissiyle paralellik gösterdiğini belirtmektedir.

"Boşnak asıllı Türküm. Kökenimiz Karadağ'dan zulümden gelenlerdir. Orada yaşamayı düşünmem çünkü alışamam. Bir gün orada kalmaya yetiyor çünkü o manevi duygu tatmin oluyor. Akrabalarım geliyor biz gidiyoruz, bir daha giderim onları ziyarete." Katılıma 10

Tarihsel süreç, sosyo-kültürel durum, motivasyon, yabancılaşma ve güvenlik, sosyal (toplumsal) kimlik olmak üzere beş boyut altında ata toprakları olan Balkanlara seyahat eden kişilerin sosyolojik bir analizi yapılmaya çalışılmıştır. Bu bağlamda, kişilerin geçmişte zorunlu göçe dair tarihsel bilgilerinin olduğu, sosyal ve kültürel değerlerini yaşatmaya ve bunları gelecek kuşaklara da aktarmaya çalıştıkları tespit edilmiştir. Nitekim katılımcıların geneli kendileri "Boşnak asıllı Türküm", "Arnavut asıllı Türküm" şeklinde tanımlamakta ve etnik kökenlerini yok saymamaktadırlar. Katılımcılar diaspora turizmi kapsamında Balkanlara yaptıkları seyahatlerde yeni bilgiler edindiklerini, bazen hiç tanımadıkları akrabalarını bulduklarını, dedelerinin/ anneannelerinin/babalarının anlattıkları olayları, geçmişe ait izleri bizzat yerinde yaşadıklarını dile getirmektedirler. Böylece Aristoteles'in merak duygusu üzerine söylemiş olduğu "bütün insanlar doğaları gereği bilmek isterler" sözündeki gibi geçmişe ait yaşananları, kültürlerini, dillerini, gelenek ve göreneklerini daha iyi öğrenmekte ve anlamaktadırlar.

Bunun yanı sıra katılımcılar, bir turizm faaliyeti içerisinde olsalar da Balkanlarda kendileri hiç turist gibi görmediklerini, ilk kez gittiklerinde dahi bir yabancılık çekmediklerini ifade etmektedirler. Balkanlara birden fazla giden katılımcılar ise her gittiklerinde aynı sıcaklığı ve samimiyeti bulduklarını, dolayısıyla tekrar gitmeyi düşündüklerini dile getirmektedirler. Bu da diaspora turizminin katılanlar açısından tek bir sefere mahsus olmadığı, başka bir deyişle süreklilik taşıdığını göstermesi açısından önemlidir.

\section{SONUÇ VE TARTIŞMA}

Diaspora olarak adlandırılan örneklem grubu, Osmanlı Devleti'nin son dönemleri ve Türkiye Cumhuriyet ile 1954-1965 yılları arasında Balkan devletlerinden göç ettirilen Balkan asıllı Türk vatandaşlarıdır. Bu kapsamda, 2013 Mayıs - Haziran ayları içerisinde 12 günlük Balkan turuna yeni katılıp dönmüş olan toplam 11 kişi ile yarı yapılandırılmış görüşme formu aracılığıyla yüz yüze görüşmeler yapılmıştır.

Katılımcıların göç etme nedenleri hakkında bilgi sahibi oldukları görülmüştür. Göç etme nedenlerini; siyasi, dini, sosyo-kültürel ve ekonomik baskılar, kendini ifade edememe, mal varlığına el konulması, temsil hakkının elden alınması olarak sıralamışlardır.

Katılımcıların sosyo-külütrel özelliklerine bakıldığında mensubu oldukları etnik kökene ait bir takım sosyal ve kültürel etkinlikleri devam ettirdikleri görülmüştür. Ancak ata topraklarına olan ilgi ve bağlılıkta nesiller arası farklılar söz konusudur. Nesiller geçtikçe Balkan dillerini konuşan kişi sayısı azaldığı gibi, merak etme duygusu da azalmaktadır.

Katılımcıların ata topraklarına ziyaretleri; çoğunlukla akrabalarını, anne ve babanın yaşadığı yeri, doğdukları toprakları ziyaret etme, kendilerine anlatılardan dolayı oluşan merak / anlatılanları yerinde görme gibi nedenlerden gerçekleşmektedir. Öyle ki, Coles ve Timothy (2004'den aktaran lorio ve Corsale 2013) de, diaspora ve turizmin pek çok noktada örtüştüğünü; anavatana seyahat, soy ağacını araştırma, anavatan vatandaşlarının diaspora topluluklarını ziyareti (akrabalar) gibi nedenler ile gerçekleştiğini ifade etmektedirler. Bu bağlamda, çalışmada da benzer motivasyonlar ile kişilerin diaspora turizmine katıldıkları ortaya çıkmıştır.

Bununla birlikte, katılımcıların atalarının topraklarına yaptıkları ziyaretler esnasında kendilerini çok fazla turist olarak görmedikleri ve çoğunluğunun ziyaret sırasında güvenlik konusunda bir endişe yaşamadığı bulgulanmıştır. Türkiye'de daha iyi koşullarda yaşamaktan dolayı mutlu oldukları için genellikle kendilerini "Balkan asıllı Türk vatandaşı" şeklinde betimlemişlerdir. Bu da diaspora turizmine katılanların, her iki coğrafyaya da olan aidiyetlerini ortaya koymaktadır.

Bulgulardan hareketle yapılacak bir başka değerlendirme de, Argın'ın (2003) turizme yönelik yapmış olduğu "uzaktaki ev" nitelemesi ve diaspora kavramı arasındaki hem ontolojik hem de epistemolojik ilişki açısından yapılabilir. Öyle ki, turizm faaliyeti insanların ikamet ettikleri yerlerin dışına farklı amaçlarla 
yaptıkları seyahatlerden kaynaklanırken, diaspora ise insanların ikamet ettikleri yerlerin dışına zorunlu olarak göç etmesinden kaynaklanmaktadır. Dolayısıyla turizm kavramı, içerisinde aynı zamanda diaspora kavramını barındırırken, diaspora kavramı da zorunluluktan da olsa turizm kavramını kendi bünyesinde barındırmaktadır. Çünkü hangi diaspora olursa olsun, merak, kimlik arayışı ve/veya kimliğini onaylatma motivasyonları ile (Hughes ve Allen 2010; lorio ve Corsale 2013) geçmişlerini aramaya yönelik olarak turizm faaliyetine katılmaktadırlar. Diğer yandan diaspora olmayıp yalnızca gezmek, görmek, keşfetmek vb. farklı motivasyonlar ile turizme katılanlar da gittikleri farklı yerlerde ya da başka bir ifade ile "uzaktaki ev"lerinde diasporaların yaşadığı "yersizlik/yurtsuzluk" duygusunu yaşayabilirler. Nitekim, lorio ve Corsale (2013) de bu ilişkiye vurgu yapmakta ve diaspora ile turizm kavramlarının örtüştüğünü dile getirmektedirler.

Söz konusu bu ilişki beraberinde farklı etkileri de ortaya çıkarmaktadır. Sosyo-kültürel, sosyo-psikolojik, sosyo-politik açıdan üç grupta değerlendirilebilir. Sosyo-kültürel açıdan örneğin "dil ve kültür" irdelendiğin de diaspora turizminin kişilerin kendilerini ait hissettikleri etnik kökeni keşfetmelerine yol açtığını ve bunun gerek dil üzerinde gerekse kültür üzerinde olumlu etkisi olduğu söylenebilir. Öyle ki katılımcıların ifade etmiş olduğu kültür dayanışma derneklerinin kurulması, o kültüre ait yemeklerin halen yapılıyor olması, atalarının konuştukları dilleri halen biliyor ve yaşatıyor olmaları bunun bir göstergesidir. Diğer yandan sosyo-psikolojik açıdan, kişilerin diaspora turizmi kapsamında gittikleri yerlerde kendilerini yabancı ya da turist olarak hissetmemeleri de turizm - diaspora ilişkisinin olumlu bir etkisi şeklinde yorumlanabilir. Son olarak sosyo-politik açıdan diaspora turizmi, kişilerin gittikleri yerlerde geçmişe ait izleri keşfetmelerine, oradaki akrabaları ile görüşmelerine, konuşmalarına aracılık ederek o kişilerin hem toplumsal hem de politik açıdan bilgi edinebilmelerini sağlamaktadır. Bu da geçmiş ile bugün arasında bir ilişki kurabilmelerine ve bu ilişkiyi analitik açıdan değerlendirebilmelerine olanak vermektedir.

Öyle ki, Tören ve Kozak (2014) da Almanya'da yaşayan Türkler üzerine yapmış oldukları çalışmada benzer sonuçlara varmıştır. Çalışmada, Almanya'da yaşayan Türklerin diaspora turizmi kapsamında Türkiye'ye yaptıkları turlar ve bu turlar neticesinde sosyo-politik, manevi ve sosyo-psikolojik açıdan ortaya çıkan etkiler nitel analizler ile değerlendirilmiştir.

Son olarak araştırma nitel yöntemler kullanılarak gerçekleştirilmiştir. Dolayısıyla, daha sonra yapılacak çalışmaların nicel veriler ile desteklenmesi çalışmanın bilimsel gücünü de artırabilir. Ayrıca, farklı örneklem grupları ile karşılaştırmalar da yapılarak, araştırmanın özgül ağırlığı da artırılabilir. 


\section{TEŞEKKÜR}

Bu çalışmada, değerli bilgilerini bizimle paylaşan Ege Üniversitesi Sosyoloji Bölümü Öğretim Üyesi sayın Yrd.Doç. Dr. Bekir Balkız'a teşekkür ederiz.

\section{KAYNAKÇA}

Argın, Ş. (2003). Nostalji ile Ütopya Arasında (birinci baskı). İstanbul: Birikim Yayınları.

Aydın, S. (1999). Kimlik Sorunu, Ulusallı ve Türk kimliği. Ankara: Öteki Yayınları.

Başer, B. (2013). Diasporada Türk-Kürt Sorunu: Almanya ve Isveç'te İkinci Kuşak Göçmenler. İstanbul: İletişim Yayınları. Press.

Cohen, R. (1997). Global Diasporas, London: UCL

Coles, T. E. ve Timothy, D.J. (2002). Tourism, Diasporas and Space. London; New York: Routledge.

Diaspora Nedir? www.diaspora.nedir.com (Erişim Tarihi: 10/09/2013)

Duval, D.T. (2010). When Hosts Become Guests: Return Visits and Diasporic Identities in a Commonwealth Eastern Caribbean Community, Current Issues in Tourism, 6(4), 267-308.

Hughes, H. ve Allen, D. (2010). Holidays of Irish Diaspora: the Pull of the Homeland, Current Issues in Tourism, 13(1), 1-19

Iorio, M. ve Corsale, A. (2013). Diaspora and Tourism: Transylvanian and Saxons Visiting Homeland, Tourism Geographies, 15(2), 198-232

Kağıtçıbaşı, Ç. (2010). Günümüzde Insan ve Insanlar:
Sosyal Psikolojiye Giriş (12. Basım). İstanbul: Evrim Yayınevi.

Lindholm Schulz, H. ve Hammer, J. (2003). The Palestinian Diaspora: Formation of Identities and Politics of Homeland. London: Routledge.

Marx, K. (2004). Felsefe yazıları (Çeviren: A. Fethi). İstanbul: Hil Yayıncılık.

Ofluoğlu, G. ve Büyükyılmaz, O.(2008). Yabanc1laşmanın Teorik Gelişimi ve Tarihsel Süreç İçinde Fark1. Alanlarda Görünümleri, Kamu - İş Hukuku ve İktisat Dergisi, 10(1), 113-144.

Patton, M.Q. (1987). How to Use Qualitative Methods in Evaluation. Newbury Park, CA: Sage Publications Inc.

Remenninck, L. (2007). The Blackwell Enyclopedia of Sociology. United Kingdom: Blackwell Publishing.

Tören, E. ve Kozak, N. (2014). Socio Cultural Impacts of Cultural Homeland Tours on Turkish Diaspora in Germany, International Conference on Tourism and Development: Growth and Diversity Proceedings, 29-20 August, Thailand.

Yıldırım, A. ve Şimşek, H. (2011). Sosyal Bilimlerde Araştırma Yöntemleri (sekizinci baskı). Ankara: Seçkin Yayincilik.

Yin R.K. (1994). Case Study Research, Design and Methods. Thousand Oaks, California: Sage Publications Inc.

Urry, J. (2003). Mobile Cultures. http://www.lancaster.ac.uk/fass/sociology/

research/publications/papers/urry-mobile-cultures. pdf (Erişim tarihi: 04/09/2013) 
